\title{
Pengetahuan Ibu Tentang Imunisasi Booster DPT Dan Campak
}

\author{
Mother's Knowledge About DPT Booster And Campak Immunization
}

\author{
Linda Rofiasari ${ }^{1}$, Shintya Yunita Pratiwi \\ Universitas Bhakti Kencana \\ ${ }^{1}$ Email: lindarofiasari@yahoo.com
}

\begin{abstract}
ABSTRAK
Imunisasi merupakan salah satu usaha membentuk kekebalan tubuh balita agar mencegah masuknya penyakit ke dalam tubuh. Mempertahankan kekebalan tubuh balita secara optimal tidak hanya diperlukan imunisasi dasar lengkap, namun diperlukan imunisasi lanjutan salah satunya booster DPT dan campak. Kenyataan dilapangan tidak semua balita mendapatkan imunisasi secara lengkap maupun lanjutan bahkan tidak mendapatkan imunisasi dari lahir. Hal ini dibuktikan di Desa Tanjunglaya cakupan imunisasi booster DPT dan campak masih kurang yaitu cakupan imunisasi booster DPT sebesar (24\%) dan Campak (9\%). Salah satu faktor yang berpengaruh adalah pengetahuan ibu. Tujuan penelitian ini adalah untuk mengetahui pengetahuan ibu balita usia 18-24 bulan tentang imunisasi booster DPT dan Campak. Jenis penelitian ini adalah deskriptif dengan populasi 191 ibu yang mempunyai balita usia 18-24 bulan, dengan sampel 66 responden. Pengambilan data secara primer dengan analisa data univariat. Hasil penelitian menunjukkan bahwa pengetahuan ibu balita usia 18-24 bulan tentang imunisasi booster DPT dan Campak kurang. Diharapkan bagi pihak puskesmas untuk mengadakan penyuluhan tentang imunisasi booster agar ibu mengetahui pentingnya imunisasi booster.
\end{abstract}

Kata Kunci : Pengetahuan, Imunisasi Booster DPT, Campak.

ABSTRACT

Immunization is an effort to form a toddler's immune system to prevent the entry of disease into the body. Maintaining optimal infant immunity is not only required for complete basic immunization, but for advanced immunization, one of which is DPT and measles booster. In reality, not all toddlers get complete or advanced immunization even do not get immunizations from birth. This was proven in Tanjunglaya Village, the coverage of DPT and measles booster immunization was still low, namely DPT booster immunization coverage was (24\%) and Measles (9\%). One influential factor was mother's knowledge. The purpose of this study was to determine the knowledge of mothers of toddlers aged 18-24 months about DPT and Measles booster immunization. This type of research was descriptive with a population of 191 mothers who have toddlers aged 18-24 months, with a sample of 66 respondents. Primary data collection with univariate data analysis. The results showed that the knowledge of mothers of toddlers aged 18-24 months about DPT and Measles booster immunization was lacking. It was expected that the puskesmas will conduct counseling on booster immunization so that the mother knew the importance of booster immunization.

Keywords: Knowledge, DPT Booster Immunization, Measles.

\section{PENDAHULUAN}

Penyakit menular masih menjadi permasalahan kesehatan masyarakat yang menimbulkan kesakitan, kematian, dan kecacatan yang tinggi sehingga perlu dilakukan penyelenggaraan penanggulangan melalui upaya

preventif, pengendalian, dan 
pemberantasan yang efektif dan efisien. Penanggulangan penyakit menular merupakan upaya kesehatan yang mengutamakan aspek preventif dan promotif yang diajukan menurunkan angka kecacatan, kesakitan, dan kematian. Kemudian membatasi penularan serta penyebaran penyakit supaya tidak meluas serta berpotensi menyebabkan kejadian luar biasa atau wabah. Salah satu upaya preventif tersebut adalah dengan imunisasi.

Imunisasi merupakan salah satu jenis usaha yang dapat memberikan kekebalan pada anak dengan cara memasukkan vaksin ke dalam tubuh yang bertujuan untuk membentuk zat anti untuk mencegah terhadap penyakit yang dapat dicegah dengan imunisasi diantaranya adalah polio, campak, hepatitis B, tetanus, pertusis, difteri, pneumonia, dan miningitis. Imunisasi yang termasuk imunisasi Dasar adalah Hepatitis B, BCG, DPT-HB-Hib, polio, dan campak. Adapun imunisasi booster (lanjutan) merupakan kegiatan yang bertujuan untuk menjamin terjaganya tingkat imunitas pada anak balita dibawah dua tahun, anak usia sekolah, dan wanita usia subur (WUS) termasuk ibu hamil. Sasaran imunisasi booster adalah imunisasi DPT dan Campak khususnya pada balita dibawah dua tahun (Baduta).

Balita adalah anak usia dibawah lima tahun atau usia 12-59 bulan. Balita termasuk sebagai tahapan perkembangan anak yang cukup rentan terhadap berbagai serangan penyakit. $^{3}$ Ketika anak usia dibawah dua tahun (Baduta), mulai diberikan imunisasi tahap kedua yang di kenal dengan imunisasi lanjutan atau imunisasi ulangan (Booster). Imunisasi tahap kedua ini sesuai dengan kebijakan Kementrian Kesehatan dimana dalam kajiannya menyimpulkan bahwa imuninisasi DPT-HB-Hib dan Campak diberikan dalam 2 tahap, yakni tahap pertama imunissasi DPT-HB-Hib diberikan sebanyak 3 kali dan Campak sebanyak 1 kali (Imunisasi Dasar). Dilanjutkan tahap kedua pada rentan usia 18-24 bulan yang berguna untuk mempertahankan dan meningkatkan titer antibodi pada anak yang menurun pada kasus penyakit DPT dan Campak.

Penyakit DPT diantaranya merupakan penyakit difteri, pertusis, dan tetanus. Difteri merupakan penyakit yang disebabkan oleh bakteri Corynebacterium diphtheria. Difteri bersifat ganas, mudah menular dan menyerang terutama saluran napas 
bagian atas. Difteri disebabkan oleh bakteri yang ditemukan di mulut, tenggorokan dan hidung. Pertusis merupakan suatu penyakit yang disebabkan oleh kuman Bordetella Pertussis. Kuman ini megeluarkan toksin yang menyebabkan ambang rangsang batuk menjadi rendah sehingga bila terjadi sedikit saja rangsangan akan terjadi batuk yang hebat dan lama. Batuk rejan adalah penyakit yang menyerang saluran udara dan pernapasan dan sangat mudah menular.Tetanus merupakan penyakit yang disebabkan oleh infeksi kuman Clostridium tetani. Kuman ini bersifat anaerob, sehingga dapat hidup pada lingungan yang tidak terdapat zat asam (oksigen). Tetanus disebabkan oleh bakteri yang berada di tanah, debu, dan kotoran hewan.

Menurut data kementerian Kesehatan Republik Indonesia, pada tahun 2018 cakupan Imunisasi Booster balita usia dibawah dua tahun harus mencapai target yang ditentukan yaitu $70 \%$.

Berdasarkan studi pendahuluan yang dilakukan di Dinas Kesehatan Kabupaten Bandung, dengan menanyakan data Imunisasi Booster DPT dan Campak maka didapatkan bahwa, Puskesmas yang memiliki cakupan imunisasi booster yang rendah diantarannya adalah Puskesmas Cikancung dengan 5 Desa diantaranya Desa Mandalasari imunisasi booster DPT sebesar (21\%) dan Campak (13\%), Desa Cikancung imunisasi booster DPT sebesar (145\%) dan Campak (131\%), Desa Cikasungka imunisasi booster DPT sebesar (50\%) dan Campak (20\%), Desa Tanjunglaya imunisasi booster DPT sebesar (24\%) dan Campak (9\%), Desa Hegarmanah imunisasi booster DPT sebesar (50\%) dan Campak (32\%).

Pengetahuan ibu merupakan faktor penting bagi tercapainya derajat kesehatan di dalam rumah tangga, termasuk didalamnya pemberian imunisasi kepada anak sebagai upaya preventif terjadinya penyakit. Ibu yang cenderung memiliki pengetahuan rendah cenderung memiliki peran yang lebih kecil dalam keluarga. Hal tersebut menjadikan cakupan imunisasi sering rendah di pedesaan seperti lokasi penelitian. Sesuai dengan kondisi kesehatan di Daerah Jawa Barat masih memprihatinkan karena ibu tidak dapat optimal menyediakan kehidupan yang sehat bagi anak-anaknya. Faktor yang mempengaruhi adalah budaya, status perempuan (termasuk pendidikan) dan 
kurangnya pengertian bahwa kesehatan anak adalah hal yang penting untuk diusahakan.

Berdasarkan studi pendahuluan dari 10 ibu yang memiliki balita, sebanyak 8 ibu tidak mengetahui pentingnya imunisasi booster yang diberikan pada anak, ibu hanya mengetahui bahwa anaknya sudah cukup dengan mendapatkan imunisasi dasar saja.

Berdasarkan latar belakang diatas maka peneliti tertarik untuk mengambil judul "Pengetahuan Ibu Balita Tentang Imunisasi Booster DPT dan Campak".

\section{METODE PENELITIAN}

Jenis penelitian yang digunakan dalam penelitian ini adalah jenis penelitian Deskriptif yaitu untuk mengetahui Gambaran Pengetahuan Ibu Balita Usia 18-24 Bulan Tentang Imunisasi Booster DPT dan Campak.

Variabel adalah sesuatu yang digunakan . Pengetahuan Ibu Balita Usia 18-24 Bulan Tentang Imunisasi Booster DPT dan Campak.

$$
\text { Populasi adalah wilayah }
$$
generalisasi yang terdiri atas objek atau subjek yang mempunyai kuantitas dan karakteristik tertentu yang ditetapkan oleh peneliti dan kemudian ditarik kesimpulannya populasi dalam penelitian ini adalah seluruh ibu yang mempunyai balita usia 18-24 bulan di Desa Tanjunglaya berjumlah 191 orang.

\section{HASIL DAN PEMBAHASAN}

Tabel 1 Distribusi Frekuensi Pengetahuan Ibu Balita Usia 18-24 Bulan Tentang Imunisasi Booster DPT dan Campak

\begin{tabular}{ccc}
$\begin{array}{c}\text { Tingkat } \\
\text { Pengetahuan }\end{array}$ & $\begin{array}{c}\text { Jumlah / } \\
\text { Frekuensi } \\
\text { N = 66 }\end{array}$ & $\begin{array}{c}\text { Presentasi } \\
(\%)\end{array}$ \\
\hline Baik & 9 & $13,6 \%$ \\
Cukup & 20 & $30,3 \%$ \\
Kurang & 37 & $56,1 \%$ \\
Jumlah & $\mathbf{6 6}$ & $\mathbf{1 0 0 \%}$ \\
\hline
\end{tabular}

Dari tabel 1 didapatkan hasil bahwa lebih dari setengah responden yaitu sebanyak 37 orang $(56,1 \%)$ berpengetahuan kurang, dan sebagian kecil yaitu sebanyak 9 orang $(13,6 \%)$ berpengetahuan baik tentang imunisasi booster DPT dan campak.

Pengetahuan adalah hasil tahu, dan ini terjadi setelah orang melakukan pengindraan terhadap suatu objek tertentu. Pengindraan terjadi melalui panca indra mansia, yakni indra penglihatan, pendengaran, penciuman, rasa dan raba.

Hasil penelitian didapatkan pengetahuan ibu balita tentang pengetahuan imunisasi booster DPT dan Campak lebih dari setengah responden berpengetahuan kurang yaitu sebanyak 37 orang $(56,1 \%)$. Hal diatas tidak akan 
terjadi jika seorang ibu mempunyai pengetahuan yang baik. Kurangnya pengetahuan ini bisa menjadikan salah tindakan yang dilakukan oleh ibu. Hal ini sesuai dengan pendapat Notoatmodjo yang mengemukakan bahwa pengetahuan dapat dijadikan pertimbangan oleh seseorang saat seseorang tersebut akan mengambil suatu tindakan.

Dampak dari kurangnya pengetahuan ibu ini bagi anak adalah bahwa dengan pengetahuan yang kurang akan mengakibatkan ibu kurang mengetahui manfaat dari imunisasi Booster DPT dan Campak tersebut, sehingga dimungkinkan ibu tidak akan membawa anaknya untuk di imunisasi booster DPT dan campak, akibat yang ditimbulkan untuk anaknya adalah, kurangnnya kekebalan tubuh terhadap penyakit, serta menurunya sistem kekebalan tubuh anak karena tidak mendapatkan vaksin atau imunisasi khususnya imunisasi booster DPT dan campak.

Penelitian ini diperkuat dengan adanya penelitian yang dilakukan oleh Ayu Fitriansyah bahwa sebanyak 29 dari 35 orang responden termasuk kedalam kategori kurang, kurangnnya pengetahuan ibu ini juga dapat disebabkan karena kurangnya konseling ibu-ibu yang memiliki balita agar dapat memahami imunisasi apa saja yang wajib diberikan kepada balitanya.

Berdasarkan pendapat diatas, dihubungkan dengan penelitian ini yakni bagi ibu yang masih memiliki pengetahuan kurang tentang imunisasi booster yaitu ditandai dengan ketidaktahuan ibu tentang imunisasi booster DPT dan campak yang diberikan pada anak, ibu hanya mengetahui bahwa anaknya sudah mendapatkan imunisasi dasar atau imunisasi saat anak berusia kurang dari satu tahun saja. Hal ini disebabkan karena petugas kesehatan kurang dapat mengatur para ibu pada saat melakukan penyuluhan yang menjadikan suasana menjadi kurang efektif dan apa yang disampaikan petugas kesehatan pada saat penyuluhan kurang tersampaikan sehingga ibu kurang faham. Dengan demikian, dapat mempengaruhi tingkat pengetahuan responden mengenai Imunisasi Booster dan lainnya. 
Tabel 2 Distribusi Frekuensi Pengetahuan Ibu Balita Usia 18-24 Bulan Tentang Pengertian Imunisasi Booster DPT dan Campak

\begin{tabular}{ccc}
\hline $\begin{array}{c}\text { Tingkat } \\
\text { Pengetahuan }\end{array}$ & $\begin{array}{c}\text { Jumlah / } \\
\text { Frekuensi } \\
\text { N = 66 }\end{array}$ & $\begin{array}{c}\text { Presentasi } \\
(\mathbf{\%})\end{array}$ \\
\hline Baik & 17 & $25,8 \%$ \\
Cukup & 18 & $27,2 \%$ \\
Kurang & 31 & $47 \%$ \\
Jumlah & $\mathbf{6 6}$ & $\mathbf{1 0 0 \%}$ \\
\hline
\end{tabular}

Dari tabel 2 didapatkaan hasil bahwa hampir setengah dari responden yaitu sebanyak 31 orang (47\%) berpengetahuan kurang mengenai pengertian imunisasi booster DPT dan campak, dan sebagian kecil berpengetahuan baik yaitu sebanyak 17 orang $(25,8 \%)$.

Pengetahuan adalah sebagai suatu pembentukan yang terus-menerus oleh seseorang yang setiap saat mengalami reorganisasi karena adanya pemahaman-pemahaman baru. Imunisasi adalah suatu upaya untuk menimbulkan/ meningkatkan kekebalan seseorang secara aktif terhadap suatu penyakit, sehingga apabila suatu saat terpajan dengan penyakit tersebut tidak akan sakit atau hanya mengalami sakit ringan.

Berdasarkan penelitian diatas maka dapat diketahui lebih dari setengahnya responden memiliki hampir setengah dari responden yaitu sebanyak $\quad 31 \quad$ orang $(47 \%)$ berpengetahuan kurang. Penelitian ini diperkuat dengan penelitian yang dilakukan Nurazisah Tahun 2012 tentang Imunisasi Booster pada Anak Di Kota Makassar, Hasil penelitian menunjukkan dari 135 responden $(29,6 \%)$ memiliki pengetahuan kurang tentang definisi imunisasi booster. Hal ini dikarenakan ibu belum mengetahui dengan jelas tentang pengertian imunisasi booster maka dari itu bagi ibu yang masih memiliki pengetahuan kurang tentang pengertian imunisasi booster guna meningkatkan pengetahuan ibu diharapkan ibu dapat mencari informasi sebanyak-banyaknya tentang imunisasi booster DPT dan campak.

Tabel 3 Distribusi Frekuensi Pengetahuan Ibu Balita Usia 18-24 Bulan Tentang Tujuan Imunisasi Booster DPT dan Campak

\begin{tabular}{ccc}
\hline $\begin{array}{c}\text { Tingkat } \\
\text { Pengetahuan }\end{array}$ & $\begin{array}{c}\text { Jumlah / } \\
\text { Frekuensi } \\
\mathbf{N = 6 6}\end{array}$ & $\begin{array}{c}\text { Presentasi } \\
\mathbf{( \% )}\end{array}$ \\
\hline Baik & 3 & $4,5 \%$ \\
Cukup & 18 & $27,3 \%$ \\
Kurang & 45 & $68,2 \%$ \\
Jumlah & $\mathbf{6 6}$ & $\mathbf{1 0 0 \%}$ \\
\hline
\end{tabular}

Dari tabel 3 didapatkaan hasil bahwa hampir sebagian besar responden yaitu sebanyak 45 orang $(68,2 \%)$ mengenai tujuan imunisasi booster DPT 
dan campak berpengetahuan kurang, dan sebagian kecil responden yaitu sebanyak 3 orang $(4,5 \%)$ berpengetahuan baik.

\section{Imunisasi}

DPT-HB-Hib digunakan untuk mencegah terhadap difteri, tetanus, pertusis (batuk rejan), hepatitis B, dan infeksi Haemophilus influenzae tipe $\mathrm{b}$ secara simultan. Imunisasi Campak digunakan untuk pemberian kekebalan aktif terhadap penyakit campak.

Berdasarkan penelitian diatas maka dapat diketahui hampir sebagian besar responden yaitu sebanyak 45 orang $(68,2 \%)$ mengenai tujuan imunisasi booster DPT dan campak berpengetahuan kurang, kurangnya pengetahuan ibu tentang tujuan imunisasi booster DPT dan campak ini disebabkan karena kurannya sosialisasi tentang imunisasi tujuan imunisasi booster DPT dan campak sosialisasi imunisasi hanya dititik beratkan pada imunisasi wajib atau imunisasi dasar saja sehingga imunisasi booster DPT dan campak dimasyarakat kurang dikenal, sehingga para ibu pun tidak mengetahui kapan sebaiknya imunisasi booster DPT dan campak diberikan.

Penelitian ini diperkuat dengan penelitian yang dilakukan Maghfira
Rusmiady Tahun 2018, tentang faktor yang mempengaruhi kelengkapan imunisasi ulangan booster DPT dan campak. Berdasarkan hasil analisis, didapatkan $42,9 \%$ responden memiliki status imunisasi lanjutan booster DPT dan campak lengkap dan $57,1 \%$ tidak lengkap, pengetahuan ibu yang berhubungan dengan tujuan kelengkapan status imuniasi lanjutan booster DPT dan campak.

Tabel 4 Distribusi Frekuensi Pengetahuan Ibu Balita Usia 18-24 Bulan Tentang Jenis Imunisasi Booster DPT dan Campak

\begin{tabular}{ccc}
$\begin{array}{c}\text { Tingkat } \\
\text { Pengetahuan }\end{array}$ & $\begin{array}{c}\text { Jumlah / } \\
\text { Frekuensi } \\
\text { N = 66 }\end{array}$ & $\begin{array}{c}\text { Presentasi } \\
(\%)\end{array}$ \\
\hline Baik & 5 & $7,6 \%$ \\
Cukup & 26 & $39,4 \%$ \\
Kurang & 35 & $53 \%$ \\
Jumlah & $\mathbf{6 6}$ & $\mathbf{1 0 0 \%}$ \\
\hline
\end{tabular}

Dari tabel 4 didapatkan hasil bahwa sebagian besar responden yaitu sebanyak $\quad 35 \quad$ orang berpengetahuan kurang tentang jenis imunisasi booster DPT dan campak, dan sebagian kecil responden yaitu sebanyak 5 orang $(7,6 \%)$ berpengetahuan baik.

Indonesia terdapat jenis imunisasi yang diwajibkan oleh Pemerintah (imunisasi dasar) dan yang hanya dianjurkan. Imunisasi wajib di Indonesia sebagaimana telah diwajibkan 
oleh WHO ditambah dengan Hepatitis

$\mathrm{B}$, sedangkan imunisasi yang hanya dianjurkan oleh pemerintah dapat digunakan untuk mencegah suatu kejadian yang luar biasas atau penyakit epidemik. DPT adalah singkatan dari diteri, pertusis, dan tetanis. Imunisasi DPT adalah salah satu vaksinasi yang wajib diberikan kepada balita. Imunisasi Campak adalah vaksin untuk mencegah penyakit campak.

Mempertahankan kekebalan tubuh secara optimal tidak hanya dengan mendapatkan imunisasi dasar lengkap, namun dengan mendapatkan imunisasi booster. Imunisasi booster merupakan pemberian kekebalan setelah imunisasi dasar atau pada anak usia sekolah dasar (SD) kelas I dan apabila sampai dengan usia 5 tahun anak belum pernah memperoleh imunisasi hepatitis B, maka secepatnnya di berikan imunisasi Hepatitis dengan jadwal 3 kali pemberian

Imunisasi Booster sangat penting untuk meningkatkan kembali respons imun terhadap vaksin yang sudah semakin menurun seiring dengan bertambahnya usia anak. Jika tidak dilakukan booster, anak berisiko tidak terlindungi saat terkena penyakit yang seharusnya bisa dicegah, seperti wabah difteri. Jika terjadi wabah, imunisasi ulang bisa langsung diberikan, selain melakukan imunisasi sesuai jadwal dan memberikan booster.

Berdasarkan penelitian diatas maka dapat diketahui sebagian besar responden yaitu sebanyak 35 orang (53\%) berpengetahuan kurang tentang jenis imunisasi booster DPT dan campak, kurangnya penetahuan ibu tentang jenis imunisasi booster DPT dan campak ini disebabkan keterbatasan pengetahuan ibu yang ibu dapat dari petugas kesehatan seperti bidan ataupun tenaga kesehatan lainya tentang jenin imunisasi booster seperti imunisasi booster DPT dan campak. Berdasarkan penelitian yang dilakukan oleh Aufarahman Tahun 2012, tentang hubungan tingkat pengetahuan ibu tentang imunisasi dengan kepatuhan jadwal imunisasi booster DPT dan campak, sebanyak 40 responden hasil penelitian didapatkan kepatuhan pemberian imunisasi campak dan berada dalam kategori tidak patuh $(70.0 \%)$.

Hal ini juga sejalan dengan penelitian Josiman (2012) yang menyatakan bahwa pengetahuan memiliki keeratan dengan kelengkapan imunisasi. 
Tabel 5 Distribusi Frekuensi Pengetahuan Ibu Balita Usia 18-24 Bulan Tentang Efek Samping Imunisasi Booster DPT dan Campak

\begin{tabular}{ccc}
\hline $\begin{array}{c}\text { Tingkat } \\
\text { Pengetahuan }\end{array}$ & $\begin{array}{c}\text { Jumlah / } \\
\text { Frekuensi } \\
\text { N = 66 }\end{array}$ & $\begin{array}{c}\text { Presentasi } \\
(\%)\end{array}$ \\
\hline Baik & 4 & $6 \%$ \\
Cukup & 24 & $36,4 \%$ \\
Kurang & 38 & $57,6 \%$ \\
Jumlah & $\mathbf{6 6}$ & $\mathbf{1 0 0 \%}$ \\
\hline
\end{tabular}

Dari tabel 5 didapatkan hasil bahwa sebagian besar responden yaitu sebanyak 38 orang $(57,6 \%)$ berpengetahuan kurang tentang efek samping imunisasi booster DPT dan campak, dan sebagian kecil responden yaitu sebanyak 4 orang $(6 \%)$ berpengetahuan baik.

Pengetahuan merupakan hasil dari "tahu" dan ini terjadi setelah melakukan pengindraan terhadap sesuatu objek tertentu. Pengindraan terjadi melalui panca indera manusia, yakni indera penglihatan, pendengaran, penciuman, rasa, dan raba. Sebagian besar pengetahuan manusia diperoleh melaui mata dan telinga.

Berdasarkan penelitian diatas maka dapat diketahui sebagian besar responden yaitu sebanyak 38 orang $(57,6 \%)$ berpengetahuan kurang tentang efek samping imunisasi booster DPT dan campak, kurangnya penetahuan ibu tentang jenis imunisasi booster DPT dan campak ini disebabkan keterbatasan pengetahuan ibu yang ibu dapat dari petugas kesehatan seperti bidan ataupun tenaga kesehatan lainya tentang dampak positif dari pemberian imunisasi booster DPT dan campak ataupun dampak negatif dari pemberian imunisasi seperti halnya seperti imunisasi pada umumnya dapat menyebabkan panas setelah pemberian imunisasi.

Berdasarkan penelitian yang dilakukan oleh Amin Dewi Fitriyani, Tahun 2013 tentang tingkat pengetahuan Ibu tentang Imunisasi booster DPT dan campak di Mojogendang Karangayar, hasil penelitian didapatkan Tingkat pengetahuan ibu tentang efek samping imunisasi booster DPT dan campak pada kategori baik sebanyak 5 responden (16,67\%), kategori cukup 22 responden $(73,33 \%)$, kategori kurang 3 responden $(10 \%)$.

Tabel 6 Distribusi Frekuensi Pengetahuan Ibu Balita Usia 18-24 Bulan Tentang Kontraindikasi Imunisasi Booster DPT dan Campak

\begin{tabular}{ccc}
\hline $\begin{array}{c}\text { Tingkat } \\
\text { Pengetahuan }\end{array}$ & $\begin{array}{c}\text { Jumlah / } \\
\text { Frekuensi } \\
\text { N = 66 }\end{array}$ & $\begin{array}{c}\text { Present } \\
\text { asi } \\
(\mathbf{\%})\end{array}$ \\
\hline Baik & 15 & $22,7 \%$ \\
Cukup & 0 & $0 \%$ \\
Kurang & 51 & $77,3 \%$ \\
Jumlah & $\mathbf{6 6}$ & $\mathbf{1 0 0 \%}$ \\
\hline
\end{tabular}


Dari tabel 6 didapatkan hasil bahwa sebagian besar responden yaitu sebanyak 51 orang $(77,3 \%)$ berpengetahuan kurang, dan sebagian kecil yaitu sebanyak 15 orang $(22,7 \%)$ berpengetahuan baik tentang kontraindikasi imunisasi booster DPT dan campak.

Pengetahuan tentang kesehatan adalah mencakup apa yang diketahui oleh seseorang terhadap cara-cara memelihara kesehatan. Indikator pengetahuan kesehatan adalah "Tingginya Pengetahuan" responden tentang kesehatan, atau besarnya persentase kelompok responden atau masyarakat tentang variabel-variabel atau komponen-komponen kesehatan. ${ }^{8}$ Kontraindikasi adalah suatu kondisi atau faktor yang berfungsi sebagai alasan untuk mencegah tindakan medis tertentu karena berbahaya bagi pasien.

Berdasarkan penelitian diatas maka dapat diketahui sebagian besar responden yaitu sebanyak 51 orang (77,3\%). Hal ini dapat dijelaskan bahwa kurangnya pengetahuan seseorang dalam mengetahui tentang kontraindikasi imunisasi booster DPT dan Campak. Penelitian ini diperkuat dengan penelitian yang dilakukan oleh Heriani Tahun 2013 tentang hubungan tingkat pengetahuan dan perilaku ibu terhadap kontraindikasi dalam melakukan imunisasi DPT dan Campak, dari 78 responden didapatkan $69,2 \% \%$ responden yang berpengetahuan kurang.

\section{SIMPULAN DAN SARAN}

Berdasarkan hasil penelitian dan pembahasan mengenai Pengetahuan Ibu Balita Usia 18-24 Bulan Tentang Imunisasi Booster DPT dan Campak di Desa Tanjunglaya Wilayah Kerja Puskesmas Cikancung Kabupaten Bandung tahun 2019, dapat disimpulkan bahwa:

1. Lebih dari setengah responden berpengetahuan kurang tentang pengetahuan imunisasi booster DPT dan Campak.

2. Hampir setengah dari responden berpengetahuan kurang tentang pengertian imunisasi booster DPT dan Campak.

3. Sebagian besar responden berpengetahuan kurang tentang tujuan imunisasi booster DPT dan Campak.

4. Lebih dari setengah responden berpengetahuan kurang tentang jenis imunisasi booster DPT dan Campak. 
5. Lebih dari setengah responden berpengetahuan kurang tentang efek samping imunisasi booster DPT dan Campak.

6. Sebagian besar responden berpengetahuan kurang tentang kontraindikasi imunisasi booster DPT dan Campak.

Dengan adanya hasil penelitian ini diharapkan kepada petugaas kesehatan untuk lebih meningkatkan efiktifitas pada saat KIE ( Komunisasi, Informasi dan Edukasi) seperti penyuluhan, memberikan konseling yang menjelaskan tentang imunisasi booster, dimana imunisasi sebagai bentuk pencegahan terhadap penyakit. Dan diharapkan dapat menjadi tambahan wawasan ilmu pengetahuan tentang kebidanan khususnya tentang imunisasi booster, serta dapat menjadi bahan acuan bagi peneliti lain dalam meneliti lebih lanjut mengenai faktor-faktor yang mempengaruhi Imunisasi booster DPT dan campak.

\section{DAFTAR PUSTAKA}

Alfa Kurnia.2012. Pentingnya Booster Vaksin. http://momsguideindonesia.com
Bandung DK. Cakupan Imunisasi. 2018.

Budiman, Riyanto A. Kapita Selekta Kuesioner Pengetahuan dan Sikap dalam Penelitian Kesehatan. Jakarta: Salemba MediKa; 2013.

Josiman A. 2012. Hubungan antara Tingkat Pengetahuan Ibu tentang Imunisasi dengan Status Kelengkapan Imunisasi Dasar Pada Bayi di Wilayah Kerja Puskesmas Depok 1 Yogyakarta. Universitas Respati Yogyakarta

KemenkesRI. Pengendalian Penyakit dan Kesehatan Lingkungan 2015.

KemenkesRI. Berikan Anak Imunisasi Rutin Lengkap. 2018.

KemenkesRI. Buku Ajar Imunisasi. 2015;2.

Mulasari SA. Pencapaian Cakupan Imunisasi. 2013.

Notoatmodjo. Metodologi Penelitian Kesehatan. Jakarta: PT Rineka Cipta; 2015.

Notoatmodjo. Metodologi Penelitian Kesehatan. 2018.

PermenkesRI. Penyelenggaraan Imunisasi. 2017.

Proverawati A, Andhini CSD. Imunisasi dan Vaksinasi. Yogyakarta: Nuha Offset; 2010.

Ranuh. Pedoman Imunisasi di Indonesia. Jakarta: Badan Penerbit Ikatan Dokter Anak Indonesia; 2008.

RI PDdIK. 2015.

Yuliani, S. tingkat pengetahuan siswi tentang dismenorea di smk jumantono karya tulis ilmiah. 2015. 